\title{
A CONTEXTUAL PROBLEM BASED OF LOCAL WISDOM IMPROVE THE ABILITY TO SOLVING A WORD PROBLEM MATHEMATICS STUDENTS OF ELEMENTARY SCHOOL
}

\author{
Riza Fatimah Zahrah"1, Winarti Dwi Febriani ${ }^{2}$ \\ ${ }^{1}$ Universitas Perjuangan Tasikmalaya \\ ${ }^{2}$ Universitas Perjuangan Tasikmalaya \\ ${ }^{1}$ rizafatimah@ unper.ac.id ${ }^{2}$ winartidwi@unper.ac.id,
}

\begin{abstract}
The background of the study are the results of the study in the year 2013 that has been carried out, the capacity of finishing to solve word problems still a big the difficulties encountered by primary school student on math. First, the students was difficult to understand content from to word problems which it is served. So that it would be a much trouble, students hard to change the words of story into mathematics modelling. The purpose of this research is to had a clear grasp of concerning the improvement of the the ability for solving the word problems mathematics with is using it based math thats why chose without abandoning the local wisdom. A Contextual problem of Mathematics at class was serve in sunda language and using the game of sunda's cultured (for example: congklak). This research used a quantitative approach with the methods quasi experiment. The experimental methods specious or quasi experiment use class experimentation and class control. Research was implemented in public primary schools 1 suganangan as a class experimentation and public primary schools 2 suganangan as a class control. Class experiment given learning with using it contextual mathematics based local with $\mathrm{N}$-gain 0.51 medium category.
\end{abstract}

Keywords: Contextual Problem based on Local Wisdom

\begin{abstract}
Abstrak
Latar belakang dari penelitian ini adalah hasil penelitian pada tahun 2013 yang telah dilakukan, bahwa kemampuan menyelesaikan soal cerita masih menjadi kesulitan yang dihadapi oleh siswa Sekolah Dasar pada mata pelajaran Matematika. Kesulitan pertama siswa adalah sulit memahami konten dari soal cerita yang disajikan. Sehingga akan melahirkan kesulitan yang selanjutnya yaitu, siswa kesulitan untuk mengubah kalimat cerita menjadi kalimat matematika. Pada tahap melakukan operasi hitung juga siswa masih mengalami kesulitan. Tujuan penelitian ini adalah untuk memperoleh gambaran tentang peningkatan kemampuan menyelesaikan soal cerita Matematika dengan menggunakan masalah kontekstual matematika berbasis kearifan lokal. Masalah kontekstual Matematika yang disajikan menggunakan bahasa sunda dan dalam pembelajaran menggunakan permainan berbudaya sunda (misalnya: congklak dan enggrang). Penelitian ini menggunakan pendekatan kuantitatif dengan metode kuasi eksperimen. Metode eksperimen semu atau kuasi eksperimen menggunakan kelas eksperimen dan kelas kontrol. Penelitian ini dilaksanakan di SD Negeri 1 Suganangan sebagai kelas eksperimen dan SD Negeri 2 Suganangan sebagai kelas kontrol yang berada di desa Suganangan Kecamatan Suganangan Kabupaten Kuningan. Kelas eksperimen diberikan pembelajaran dengan menggunakan masalah kontekstual matematika berbasis kearifan lokal mengalami peningkatan dengan N-Gain sebesar 0.51 dengan kategori sedang.
\end{abstract}

Kata Kunci: CTL, Kearifan Lokal

\section{INTRODUCTION}

Mathematics is a subjects made some study science like the number of, geometry and data processing taught starting from the level of elementary schools to senior high school. Mathematics also be the foundation for the physics, chemical, statistika and other sciences, so 
that of math the science which crucial to the development of the era of globalization and technology development .

In Zahrah (2016) that one the difficulties encountered of primary school students when studies math is doing the story. Students weak in understanding the concept of, as a result wrong have translated questions to students in the model mathematics. And also students would be wrong to do the completion of mathematical model .Students experienced difficulty in have translated the content or content of a word problem of mathematics that presented so as to make the planning has resulted in the resolution of problems. This is further strengthened with the results of the study Zahrah ( 2013 ) based on the value of god is mathematics second semester with an average 55,4 has not yet reached the value of standart (KKM) and researchers hope, that is 65 and 80 .Have been further strengthened with sheets of the answer students who look experienced difficulty on a word problem, this seems to indicate that a student experienced difficulty in resolving problem solving mathematical.

In math stressed to apply or implement science in the life. The purpose of mathematics for all primary and secondary level of education is that students be able to: (3) solve the problem which includes the ability to understand the problems, designed a mathematical model, finish, model and interpreting a solution obtained; (Depdiknas, 2006). While based on the fact that there are things that are difficult for primary school student.

According to a story about Abidin (1989: 10 ) with. presented in the form of short stories. The story he can be a life problems. colloquial or other problems. Weight problems expressed will affect the long or short story. The greater weight problems, expressed allowing the longer the story presented. Meanwhile, according to the story of the research is a math problem shaped story associated with various of subjects of taught in math in fourth grade.

According to Asih , I .M (2010: 68 ) address about story is finish about through the sequence of steps: understanding about and understands what are asked in about, followed by making model mathematics complete with a logaritm, and then solved computing and the aljabr properly. In line with opinion Salma, U. , \& Amin, S. M.(2014: 175 ):

Capability of being needed in resolving about story not only on the ability of in skill or algorithm certain. But also needed their ability to drawing up plans or strategy to be used in the resolution. To complete about story, besides students are required aware of information that served must be analyzes information given in about. Information analyzed in order to make the choice and decisions will be taken in finish te problem. 
The stages in the completion of a word problem given in conformity to the process of solving a problem according to Polya in Maier (1995: 87) divided into several stages:

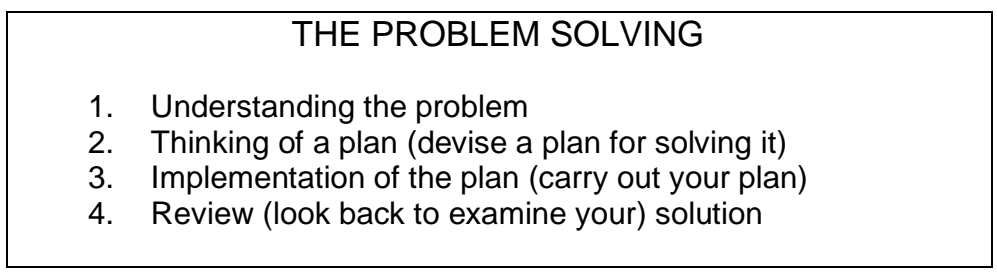

Figure 1. Problem Solving Stage

Pimta, S et al (2009: 381):

"Mathematical problem is the tool used as not only to help students develop their thinking ability but it also helps them to develop their basic skills of solving the problems especially a problem in daily life. The goal of teaching mathematic to be effective was that the students were able to solve its problems."

A math problem that is a tool that not only used to help students develop their thinking ability but it is also helping them to develop their basic skills of solving problems especially a problem in everyday life.The purpose of teaching mathematika to be that those students were able to solve the problem effectively.In line with the research results of Khatimah dan Masduki (2016: 3) this means that "problems" in problem solving tend to be complex, non-routine, open-ended, and challenging.

Nelissen (1997) defines the context as the situation that attracts attention children and which they can be recognize well. According to Johnson (2006: 58) that the context of usually likened to the environment, namely the world beyond is communicated through the intimate, space as we use every day, the context of meaningful more than days of that happens at a given place and time. So the context is the situation capable of exciting curiosity boy who is capable of being communicated environment the intimate sederhanya are something that is already known by the students.

According to Anggo ( 2011: 35 ) that the use of the context in learning mathematics made the concept of an abstract concept understood thought based on certain realistik built of a situation already known well by students. The context in this study, intended as an object, the, fact or concept that already well recognized by students that he was able to raise knowledge about this matter in the form of own working methods. According to Pena, Tayruakham, and Nuangchalerm (2006: 50) contextualized consists of three elements: situated, inquiry us 
researchers, practitioner and community of practice. That the issue of contextual when containing three, this element the conditioned, : investigation as researchers and practitioners. community practice. Simply that the issue of contextual should involve learning, investigation and students acting as researchers and there are community learning. So, students will act to conduct investigations into an issue that is presented and brought it obtained from the studies to her group.

According to Fajarini (2014: 124) local wisdom is a view of life and science as well as various life strategies in the form of activities carried out by local communities in answering various problems in meeting their needs. In a foreign language, it is often conceptualized as a local policy of "local wisdom" or local knowledge "local genious". Meanwhile, according to Rahyono (2009), local wisdom is human intelligence possessed by certain ethnic groups obtained through the experience of local communities. That is, local wisdom is the result of certain communities through their experiences and not necessarily experienced by other communities. These values will be very strongly attached to certain communities and those values have gone through a long time, throughout the existence of these communities.

Based on the opinions of experts regarding the contextual problem of mathematics and local wisdom, so it can be concluded that the contextual problem of mathematics based on local wisdom is a problem presented in learning that involves students conducting investigations, and students act as researchers and there is a learning community or learning community by upholding the values and habits of a society, in this study in particular the Sundanese. Can be in the form of language and the game habits used in contextual mathematics problems. In this study looking for a picture of a significant difference regarding the improvement of the ability to solve story problems between students who get learning using Mathematical Contextual Problems based on Local Wisdom between control class and experiment class.

\section{METHOD}

This study used a quantitative approach with the quasi experiment .According to Saodih (2005: 53) is research which are based on the philosophy that emphasizes positivism fenomena-fenomena objective and examined quantitatively. Optimization was objectivity design this research was done using angka-angka, processing statistics, the structure and control experiment . The experimental methods are specious or quasi experiment essentially equal to pure experiment, the difference is in control variables. Be only done for only one variable, that is the most dominant variable Syaodih (2005: 59). A design used is 
nonequivalentcontrol group design that is according to sugiyono ( 2009: 116 ) this design is similar to that of pretest-posttest control group design, only on this design group and the control group experiment not chosen at random. This design shows that half class (class experiment be treatment that is learning by using learning contextual teaching learning ( CTL) and class control given learning by using learning directly .

Table 1. Design research

\begin{tabular}{lccc}
\hline Group & Pretest & Treatment & Posttest \\
\hline Experiment & $\mathrm{O}_{1}$ & $\mathrm{X}$ & $\mathrm{O}_{2}$ \\
Control & $\mathrm{O}_{1}$ & - & $\mathrm{O}_{2}$ \\
\hline (Sugiono, 2010: 116$)$ & &
\end{tabular}

description:

$\mathrm{O} 1=$ pretest

$\mathrm{O} 2=$ posttest

$\mathrm{X}=$ Treatment $(\mathrm{CTL})$

The research was conducted in public primary schools a student of class IV SDN 1 Suganangan as a class experimentation and SDN 2 Sugananganas a class control. Research has been underway since july until august 2019. Instrument that is used is the test that measures the, namely the ability finish a word problem.

\section{RESULTS AND DISCUSSION}

\section{Results}

The results in this study were carried out with a quasi experimental design. Researchers conducted research on two groups of grade IV students as a source of research data at SDN 1 Suganangan as an experimental class and SDN 2 Suganangan as a control class. The two groups, at the beginning of the research the researcher conducted a pre-test and a post-test then the researcher conducted a homogeneity test on both data in the experimental class and in the control class.

The results in this study were carried out with a quasi experimental design. Researchers conducted research on two groups of grade IV students as a source of research data at SDN 1 Suganangan as an experimental class and SDN 2 Suganangan as a control class. The two groups, at the beginning of the research the researcher conducted a pre-test and a post-test then the researcher conducted a homogeneity test on both data in the experimental class and in the control class.

To answer the questions in the formulation of the problem, researchers conducted data processing using descriptive statistical tests. Beginning the testing process the 
researchers conducted a data normality test to see whether the data from the two groups were normally distributed or not. The initial mastery (pretest) conducted in the experimental class about the ability to solve the story problems of the fourth grade students of SDN 1 Suganangan and SDN 2 Suganangan is the result of research related to the ability of children before being treated with the application of Mathematical Contextual Problems based on Local Wisdom. Preliminary data about the ability to solve the story questions of the experimental class students with an average of 63.05 while the control class amounted to 46,875. The application of contextual mathematical problems based on local wisdom in the experimental class that has been conducted with the number of the first 3 meetings on 18, 24 and 25 July 2019. To find out the final ability of the fourth grade students in the experimental class and the control class a post-test was conducted on the fractional material. Following are the results of the post-test the ability to solve the experimental class story questions with an average value of 84.95 and a control class of 64,625.

To see an increase in the ability to solve the students' story problems, an N-Gain test pretest-posttest of the experimental class and the control class will be carried out, before conducting the N-Gain test previously obtained data about the N-gain itself can be seen in the following table:

Table 2. Eksperimental class N-Gain pre-test and post-test

\begin{tabular}{cccc}
\hline Name & Pretest & Posttest & N-gain \\
\hline A1 & 60 & 80 & 0.5 \\
A2 & 70 & 82 & 0.4 \\
A3 & 80 & 93 & 0.65 \\
A4 & 40 & 88 & 0.8 \\
A5 & 60 & 81 & 0.53 \\
A6 & 60 & 83 & 0.58 \\
A7 & 40 & 82 & 0.7 \\
A8 & 60 & 80 & 0.5 \\
A9 & 67 & 93 & 0.79 \\
A10 & 70 & 80 & 0.33 \\
A11 & 20 & 88 & 0.85 \\
A12 & 40 & 86 & 0.77 \\
A13 & 80 & 85 & 0.4 \\
A14 & 80 & 90 & 0.25 \\
A15 & 80 & 88 & 0.5 \\
A16 & 78 & 85 & 0.45 \\
A17 & 80 & 84 & 0.25 \\
A18 & 40 & 81 & 0.73 \\
A19 & 78 & 82 & 0.14 \\
A20 & 78 & $\mathbf{8 4 . 9 5}$ & 0.18 \\
\hline Average & $\mathbf{6 3 . 0 5}$ & & $\mathbf{0 . 5 1}$
\end{tabular}


Table 3. Control Class N-Gain pre-test dan post-test

\begin{tabular}{cccc}
\hline Name & Pretest & Posttest & N-gain \\
\hline A1 & 55 & 66 & 0.24 \\
A2 & 55 & 67 & 0.27 \\
A3 & 40 & 68 & 0.47 \\
A4 & 40 & 66 & 0.43 \\
A5 & 40 & 66 & 0.43 \\
A6 & 20 & 55 & 0.44 \\
A7 & 40 & 60 & 0.33 \\
A8 & 45 & 55 & 0.18 \\
A9 & 60 & 74 & 0.35 \\
A10 & 30 & 60 & 0.43 \\
A11 & 35 & 68 & 0.51 \\
A12 & 35 & 55 & 0.31 \\
A13 & 55 & 77 & 0.13 \\
A14 & 80 & 61 & -0.15 \\
A15 & 40 & 75 & 0.35 \\
A16 & 80 & $\mathbf{6 4 . 6 2 5}$ & -0.25 \\
\hline Average & $\mathbf{4 6 . 8 7 5}$ & & $\mathbf{0 . 2 8}$ \\
\hline
\end{tabular}

Based on table 3.1 and 3.2 shows that the n-gain of the experimental class is 0.51 with the category of sedangan and the control class is 0.28 with the low category. So it can be concluded that the n-gain of the experimental class is higher than the control class.

H0: N-Gain pre-test and post-test ability to solve mathematical story problems of experimental class and control class students with normal distribution.

H1: N-Gain pre-test and post-test ability to solve mathematical story problems of experimental class and control class students are not normally distributed.

From the results of calculations using SPSS 20.0 for windows software, the normality test results obtained in table 3.3 are as follows:

Table 4. Normality Test N-Gain Gain pre-test and post-test Ability to Complete the Problem Test Story Students in the Control Class and Experiment Class

\begin{tabular}{|c|c|c|c|c|c|c|c|}
\hline & \multirow[b]{2}{*}{ Class } & \multicolumn{3}{|c|}{ Kolmogorov-Smirnov } & \multicolumn{3}{|c|}{ Shapiro-Wilk } \\
\hline & & Statistic & df & Sig. & statistic & df & Sig. \\
\hline \multirow[t]{2}{*}{ Ngain_Persen } & Experimen $\mathrm{t}$ & 0.104 & 20 & 0.2 & 0.956 & 20 & 0.47 \\
\hline & Control & 0.185 & 16 & 0.146 & 0.83 & 16 & 0.007 \\
\hline
\end{tabular}

Based on table 3.3 showed that the N-Gain pre-test and post-test the ability to solve the story questions of the experimental class and control class for the Shapiro-Wilk normality test had significance values of $0.200>0.05$ and $0.146>0.05$ such that $\mathrm{H} 0$ was accepted at the significance level $=0.05$. That is, the N-Gain pre-test and post-test ability to solve the problem of the experimental class and the control class are normally distributed. 
Since the two N-Gain values of the control class and the experimental class were normally distributed, to see the significance of this difference the researchers conducted a parametric statistical test with the Independent sample t 2 test. T-test results of 2 independent samples of the N-Gain value between the experimental class and the control class can be seen in the following table:

Table 5. T-test 2 Independent Samples of N-Gain Data Experimental Class and Independent Samples Test Control Class

\begin{tabular}{|c|c|c|c|c|c|c|c|c|c|c|}
\hline & & \multirow{2}{*}{$\mathbf{F}$} & \multirow{2}{*}{ Sig. } & \multirow{2}{*}{$t$} & \multirow{2}{*}{ df } & \multirow{2}{*}{$\begin{array}{l}\text { Sig.(2- } \\
\text { tailed) }\end{array}$} & \multirow{2}{*}{$\begin{array}{c}\text { Mean } \\
\text { Difference }\end{array}$} & \multirow{2}{*}{$\begin{array}{l}\text { Std. Error } \\
\text { Difference }\end{array}$} & \multicolumn{2}{|c|}{$\begin{array}{l}\text { 95\% Confidence } \\
\text { Interval of the } \\
\text { Difference }\end{array}$} \\
\hline & & & & & & & & & Lower & Upper \\
\hline $\begin{array}{l}\text { Ngain } \\
\text { Pers } \\
\text { en }\end{array}$ & $\begin{array}{l}\text { Equal } \\
\text { variances } \\
\text { assumed } \\
\text { Equal } \\
\text { variances } \\
\text { not } \\
\text { assumed }\end{array}$ & 0.191 & 0.665 & 3.248 & 32.417 & 0.003 & $\begin{array}{l}23.50479 \\
23.50479\end{array}$ & $\begin{array}{l}7.24432 \\
7.23653\end{array}$ & $\begin{array}{l}8.78256 \\
8.77188\end{array}$ & 38.22702 \\
\hline
\end{tabular}

Based on table $3.4 \mathrm{t}$ test results of 2 independent samples between the $\mathrm{N}$-Gain value of the experimental class and the N-Gain value of the control class, it can be seen the difference in increased social intelligence between the experimental class SDN 1 Suganangan and the dick class SDN 2 Suganangan. The t-test results of the 2 independent samples showed a sig value of $0.003<\mathrm{a}(0.05)$ then Ho was rejected and Ha was accepted, meaning there was a significant difference in the ability to solve grade IV story questions between the experimental class SDN 1 Suganangan and control class SDN 2 Suganangan.

\section{Discussion}

Based on the findings in the field, it can be concluded that the score of the ability to solve experimental class story questions is better than the control class. This is seen from the difference in the average N-Gain score obtained, which shows that the use of mathematical contextual problems in learning multiplication and fraction sharing can improve the ability to solve students' story problems. Learning activities using this contextual problem are clearer and more meaningful so that it makes it easier for students to solve a problem presented. In accordance with the results of Zahrah's research (2019) that students have understood the purpose of the problem so that he is able to make plans, then work on planning the problem solving. When students are able to answer point $b$, it means students have been able to check back or looking back, which is the last step of the problem solving steps according to Polya. 
In carrying out problem solving, steps needed in accordance with the stages of problem solving according to Polya in Maier (1995, p. 87), namely: (1) understanding the problem (understand the problem); (2) think of a plan (devise a plan for solving it); (3) carry out your plan (carry out your plan); (4) review (look back to examine your solution). By doing this step systematically will direct students to solve the problems presented. If at stage one the understanding of the problem, students still do not understand what is meant by the problem how could students be able to make a plan of resolution. This means that by not being able to pass the first stage, it is not possible to pass the next step correctly. By using the context that is understood by students according to Zahrah (2019) able to improve the ability of students to understand the purpose of the story matter.

\section{CONCLUSION}

The next research plan is a study using the contextual problem of Mathematics by examining other local wisdom-based mathematical abilities, namely the ability to think creatively, the ability to think critically and the ability to construct a conjecture. In addition to the use of this contextual problem, the researcher plans to test a number of attitudes that arise in mathematics learning such as anxiety. Is using contextual mathematics problem based on local wisdom can eliminate student anxiety in the learning process.

\section{REFERENCES}

Abidin, Z. (1989). Studi tentang prestasi siswa kelas VI SD negeri di kodya banda Aceh dalam menyelesaikan soal hitungan dan soal cerita. Tesis. Malang: PPs IKIP Malang.

Anggo, M. (2011). Pemecahan masalah matematika kontekstual untuk meningkatkan kemampuan metakognisi siswa. Edumatica. 01 (02), hlm 35-42.

Asih, I. M. (2010). Peningkatan kemampuan siswa SMA negeri 8 Denpasar dalam menyelesaikan soal cerita pokok bahasan program linier mata pelajaran matematika.Udayana Mengabdi 10 (2): 67-71.

Depdiknas. (2006). Panduan penyusunan kurikulum tingkat satuan pendidikan. BadanStandar Nasional Pendidikan: Jakarta

Fajarini, U. (2014). Peranan kearifan lokal dalam pendidikan karakter. Sosio Didaktika: Vol. 1, No. 2 Des 2014

Gandana, G. (2015). Meningkatkan Kecerdasan Emosional Anak Usia Dini Melalui Permainan Tradisonal "Kaulinan Barudak". Tesis. SPs UPI.

Istiandaru, A., Istihapsari V., Wardono \& Mulyono. (2015). Problem based learning (pbl) dengan pendekatan realistic saintifik dan asesmen pisa untuk meningkatkan kemampuan literasi matematika. Edumatica Volume 5 (1), hlm 1-11. 
Iswinarti. (2010). Nilai-Nilai Terapeutik Permainan Tradisional Engklek Untuk Anak Usia Sekolah Dasar. Naskah Publikasi Penelitian Dasar Keilmuan. Fakultas Psikologi: Universitas Muhammadiyah Malang: Malang.

Johnson, E. B. (2006). Contextual teaching and learning. Bandung: MLC.

Khotimah, R. P., \& Masduki. (2016). Improving teaching quality and problem solving ability through contextual teaching and learning in differential equations: a lesson study approach. Journal of Research and Advances in Mathematics Education 1 (1), hlm.1

Maier, H. (1995). Kompendium didaktik matematika. Bandung: PT. Remaja Rosdakarya.

Nelissen. (1997). Thinking skill in realistic mathematics. [Online]. Diakses dari http://www.fi.uu.nl/publicaties/literatuur/6259.pdf

Pena, E. V., Bensimon, E. M., \& Colyar, J. (2006). Contextual problem defning: learning and act. Liberal Education. Hlm 48-55.

Pimta, S., Tayruakham, S., \& Nuangchalerm, P. (2009). Factors influencing mathematic problem-solving ability of sixth grade students. Journal of social Sciences 5(4): 381-385. Thailand.

Rahyono. F.X. (2009). Kearifan Budaya dalam Kata. Jakarta: Wedatama Widyasastra.

Salma, U., \& Amin, S. M. (2014). Profil kemampuan estimasi siswa sekolah dasar dalam menyelesaikan soal cerita. Jurnal Ilmiah Pendidikan Matematika 3 (1), hlm. 172-180.

Suharsimi, A. (2013). Prosedur penelitian (suatu pendekatan praktik). Jakarta: PT Rineka Cipta.

Zahrah, R. F. (2013). Penerapan Model Cooperative Learning Tipe Team Pair Solo Untuk Meningkatkan Kemampuan Pemecahan Masalah Matematis Siswa Pada Materi Pecahan. Skripsi pada UPI Bandung: Tidak Diterbitkan.

Zahrah, R. F. (2016). Peningkatan Kemampuan Menyelesaikan Soal Cerita dan Motivasi Belajar Siswa melalui Penggunaan Masalah Kontekstual Matematika Siswa Sekolah Dasar. Tesis pada SPs UPI Bandung: Tidak Diterbitkan

Zahrah, R. F., Y. Suryana (2019) Pendekatan Contextual Teaching Learning (Ctl) Dalam Meningkatkan Kemampuan Menyelesaikan Soal Cerita Matematika Siswa Sekolah Dasar. Tunas Bangsa Jurnal Vol 6 no 1. 